\title{
Teachers' opinions regarding the reasons for teacher victimization
}

\author{
Mustafa Özdere ${ }^{1}$ \\ ${ }^{l}$ (School of Foreign Languages, Niğde Ömer Halisdemir University)
}

\begin{abstract}
The purpose of this study is to investigate the causes of school violence against teachers based on the views of teachers. This study using mixed model was carried out in the spring term of 2015-2016 academic year with the participation of 604 teachers from 25 high school teachers working in central district of Niğde city. The data of this study was collected through a questionnaire which is made up of 5 sections. The participants were asked how big of a problem that teacher victimization is, how much they worry about their safety at school, what they think the possible reasons for the violence are, how they react in case of violence and what factors may increase teacher victimization. According to the quantitative results of the research, it is found that teachers who faced violence think teacher victimization is a much bigger problem and more worried about their safety at school than those who never faced violence. According to the qualitative results of the survey, the factors affecting the increase of teachers victimization were classified under the themes as a. institutionalrelated, b. education system-related, c. social, d. individual, e. teacher-related and f. media, \& internet
\end{abstract}

Keywords -Reasons for violence, School violence, Teacher victimization

\section{INTRODUCTION}

As an educational institution, it is very important for schools to meet the security needs of students, teachers, administrators and other employees and to feel safe for the effectiveness and efficiency of a school. The sense of trust is essential for an effective and efficient learning and teaching process, and the first and foremost element of individuals' realization of their potential is to feel safe and free themselves [1][2]. Teachers who are responsible for the social, cognitive and emotional development of students, are the most important element of an education system. Their being a victim of violence in schools cannot be tolerated violence because teachers who worry about their own security cannot fulfill their duties properly [3][4][5]. Moreover, it is also believed that violence towards teachers has negative effects not only on individual level but also institution and society [6][7]. In other words, violence towards teachers is thought to be indirectly carried out towards students, institutions and collecting [8].

When the literature is examined, it is seen that studies related to school violence usually focus on the violence towards or in-between students rather than teacher victimization. In other words, the subject of violence against teachers and other school personnel have not been paid as much attention as it should [9][7]. However, according to some studies, violence towards teachers is a much larger universal problem [10], and even that teachers are three times more likely to suffer from violence than students [11]. Some of the teachers' violence incidents reflected to the Turkish press show that the problem is very serious in Turkey.

In Turkish press, there are news about teachers who were killed, injured, beaten and hurt badly by the students or students' relations and so on. Because these events are dramatic examples, they have been able to find themselves some place at national and local news. However, country-wide surveys carried out by some associations and unions on the subject have shown that the problem is much more serious and abundant in number than it is shown on the media. Kaplan (2007, quoted [12] state that $21 \%$ of the teachers in Turkey are having problems with parents and $25,1 \%$ of the teachers are having problems with the students. According to the Turkish Education-Sen's 2015 (2016) survey, four out of every ten teachers (41.4\%) say that they face victimization at school or out of school for school-related reasons. Studies on the subject show that in countries like America, Belgium, Canada, Israel, Slovakia, Spain and Turkey the problem is universal and a serious one affecting all community members.

Studies on the subject generally show that the problem is a serious problem that needs to be studied. It is stated that coordinated cooperation of institutions, families, media and similar institutions is necessary for solution of the problem [10]. Gregory et al. [13] state that the problem is usually approached in terms of the individual characteristics of the teachers rather than the effect of the school characteristics on the problem. It is 
also thought that factors such as school size, school resources, place of school, type, education and social climate, understanding of discipline, teacher competence may also have an effect on the problem.

It is believed that teacher victimization should not be perceived as an indication of not being able to discipline students, poor education or bad behavior but as a multidimensional, multilevel problem that needs to be focused on and sought solutions as for individual, institutional and social outputs. In addition, for awarenessraising, to develop effective prevention and intervention programs, to create positive school and classroom climate, for effective learning and preventing teachers from quitting their profession, it is believed to be studied more. However, there is an impression that the researchers and the media are not paying much attention and that there are no policies or precautions that have not been very effective so far [7].

In order to develop prevention and intervention programs for preventing violence against teachers, it is important to identify the factors that are contributing to the problem in order to provide information to policy makers, educators, and other stakeholders. So it is important to resort to the views of teachers who have been subjected to violence to determine which factors cause the violence towards them. In this study, it was tried to determine how serious teachers think teacher victimization is, how concerned they are about their safety and what factors they believe cause violence towards themselves.

The purpose of this study is to determine the factors that cause violence towards the teachers according to the teacher's opinions. For this purpose, the answers the following questions are sought:

1. According to the teachers working in the high schools in Niğde;

a. How serious is violence towards teachers?

b. How much do they feel safe in their school?

c. What are the factors that affect violence towards teachers?

\section{METHOD}

The study used a convergent parallel mixed method. Mixed methods require qualitative and quantitative research in a study and the integration of their data[14]. The convergent parallel mixed method is the method in which the researcher combines qualitative and quantitative data together to provide a basis for a comprehensive analysis of the research problem. In this type of method, the researcher usually collects qualitative and quantitative data at about the same time and then integrates them while interpreting the information [14].

\subsection{Participants}

The study's universe constitutes 883 teachers working in 25 general and vocational high schools in Niğde in the spring term of 2015-2016 academic year. To obtain more reliable data, no sampling is determined and questionnaires were administered to all the teachers. However, of the 883 teachers, 620 (70.22\%) reported their opinions by responding to the questionnaire. After the collection of the questionnaires, the 16 questionnaires were excluded from the evaluation because it was found that they were partially filled.

$46 \%$ of the participants $(\mathrm{n}=278)$ were female and $54 \%(\mathrm{n}=326)$ were male teachers. In terms of education level, it was determined that $80,5 \%(\mathrm{n}=486)$ of the participants were undergraduate $(\mathrm{BA})$ and 19 , $5 \%(n=118)$ were graduate $(M A-P h D)$. In terms of occupational seniority, of the $14,6 \%(n=88)$ have been teachers for $1-5$ years, of the $19,4 \%(n=117)$ have been teachers for $6-10$ years, of the $23,3 \%(n=141)$ have been teachers for $11-15$ years, of the $27,2 \%(n=164) 16-20$ have been teachers for years and off the $15,6 \%(n=$ 94) have been teachers for 21 years and over.38.2\% of the participants $(n=231)$ were working in general and $61,8 \%(\mathrm{n}=373)$ were working in vocational high schools. In terms of the place where the school is located, it is seen that $89,1 \%(n=538)$ of the participants in the survey working in city and $10,9 \%(n=66)$ were working in rural high schools. In terms of the size of schools, $48 \%(\mathrm{n}=291)$ of the participants are working at small, 31 , $8 \%(\mathrm{n}=192)$ of the participants are working at moderate and $20 \%(\mathrm{n}=121)$ of the participants are working at very big high schools.

\subsection{Data collection instrument}

The data for this study was collected through a questionnaire. The questionnaire consists of four subsections in addition to personal information section. In the first subsection, participants were asked what they think about the seriousness of the parent-student violence towards teachers in their school in the 5-point Likert form $(1=$ a very small problem $\ldots 5=$ a very big problem $)$. In the second subsection, participants were also 
asked how concerned they are about their personal safety in terms of parent-student violence in their school in the 5-point Likert form $(1=$ not at all.....5 = very much). In the third subsection of the survey, participants were asked A. what they think the possible reasons for the violence are, B. what they did during and/or after the incident and C. what precautions they take in order to avoid facing violence. For the part A, the participants were asked to mark every possible response out of 9 responses. For the part B, the participants were asked to mark every possible response out of 17 responses. For the part $\mathrm{C}$, the participants were asked to mark every possible response out of 7 responses. In the fourth subsection, participants were asked what they think are the most important 3 factors that increase the violence against teachers in schools as an open ended question. The participants were asked to write their thoughts in an open-ended manner.

\subsection{Data Analysis}

For the analysis of the quantitative data of the study, descriptive statistics (percentage and mean values) were run to examine what the participants think of the seriousness of teacher victimization and how much worried they are about their safety in their school. In addition, frequency of the responses to the third subsection (the possible reasons for the violence, their reactions to the violence and precautions they take to avoid being be a victim) are checked. The "Mann-Whitney U Test" and "Kruskal-Wallis test" were used to see whether the teachers' perceptions about the seriousness of the problem and their level of concern about their personal safety varied according to their demographics.

For the analysis of the qualitative data of the study, the responses of the participants obtained in the fourth subsection were examined separately by the researcher and an expert and the themes were formed. After marking done based on the created theme, the coding was compared and reliability study was started. The reliability formula proposed by Huberman and Miles (1994) was used to calculate the reliability of the study. Reliability = Vision Unity / (Vision Unity + Visibility Separation) As a result of the calculation, the reliability of the survey was calculated as $82 \%$. Over $70 \%$ of the reliability calculations are considered reliable for research [15]. Thus, the result of the study is considered reliable.

\section{FINDINGS}

In this section findings from the analysis of data regarding to the cause of teacher victimization are presented in quantitative and qualitative data subheadings.

\subsection{Quantitative Data Analysis}

\subsubsection{Findings related to the magnitude of the teacher victimization problem}

In this section, the data obtained from the first subsection of the questionnaire are investigated. Table 1 shows what the participants think about the magnitude of the teacher victimization problem.

Table 1: Participants' opinions regarding the seriousness of teacher victimization

\begin{tabular}{lllll}
\hline $\begin{array}{l}\text { Participants' opinion related to the seriousness } \\
\text { of teacher victimization }\end{array}$ & $\mathrm{N}$ & $\mathrm{M}$ & Std. D. & Interpretation \\
\hline & 604 & 2,27 & 1,308 & A medium-sized problem \\
\hline Total & 604 & & & \\
\hline
\end{tabular}

As can be seen in Table 1, the participants consider the teacher victimization as a medium-sized problem. Following this, the Mann-Whitney U test analysis was run to determine whether there is a statistically significant difference between the levels of perceptions of participants about the magnitude of the problem of violence against teachers in terms of gender. Table 2 shows the results of Mann-Whitney U test.

Table 2: Gender and the perceptions of the participants about the magnitude of the problem

\begin{tabular}{llllll}
\hline Gender & $\mathrm{N}$ & Mean Rank & Sum of Ranks & $\mathrm{U}$ & $\mathrm{z}$ \\
\hline Male & 326 & 302,08 & 98479,50 & 45178,500 & \\
Female & 278 & 302,99 & 84230,50 & &,- 066 \\
\hline Total & 604 & & & \\
\hline
\end{tabular}

When the Mann-Whitney U results shown in Table 2 were examined, it was determined that there is no statistically significant difference between the perceptions of participants' perception related to the magnitude of 
the problem of violence against teachers in terms of gender $(U=45178,500 ; p>0.05)$. Considering the rank order, it can be said that men perceive the problem as bigger than women, but this difference is not enough for a statistically significant difference.

In terms of professional seniority, the Kruskal-Wallis test was conducted to determine whether there is a statistically significant difference between the levels of perceptions of participants regarding the magnitude of the problem of violence against teachers. The results obtained are given in Table 3.

Table 3: Professional Seniority and the perceptions of the participants about the magnitude of the problem

\begin{tabular}{|c|c|c|c|c|c|c|}
\hline Professional Seniority & $\mathrm{N}$ & MeanRank & sd & $\overline{\mathrm{x}}$ & $\mathrm{p}$ & Difference \\
\hline $1-5$ & 88 & 356,19 & 4 & 16,689 &, 002 & 1-5/11-15;16-20; \\
\hline $6-10$ & 117 & 318,85 & & & & $21+$ \\
\hline $11-15$ & 141 & 293,62 & & & & $6-10 / 16-20$ \\
\hline $16-20$ & 164 & 270,39 & & & & \\
\hline $21+$ & 94 & 301,24 & & & & \\
\hline Total & 604 & & & & & \\
\hline
\end{tabular}

According to the results of the analysis, it was determined that there is a statistically significant difference between the levels of perception of the participants related to the magnitude of the problem $\left(\overline{\mathrm{x}}_{(4)}=\right.$ $16,689 ; \mathrm{p}<0,05)$. A comparison of different pairs of Mann-Whitney U tests was conducted to understand which groups or groups were favored by this difference. As a result of the Mann-Whitney U analysis performed for this purpose, the difference was between the participants with professional seniority of 1-5 years and 11-15 years $(\mathrm{U}=4895 ; \mathrm{z}=-2,738, \mathrm{p}<0.005), 1-5$ years and $16-20$ years $(\mathrm{U}=-3,747 ; \mathrm{p}<0.001)$, and between $1-5$ years and $21+$ years $(U=3385,500 ; z=-2,186 ; p<0.005)$. In addition, another difference was found between participants with professional seniority of 6-10 years and those with 16-20 years of professional seniority $(\mathrm{U}=$ $8019 ; \mathrm{z}=-2,471 ; \mathrm{p}<0.005)$. Based on the findings, It can be said that participants who are newer in the profession than others are more aware of the problem than others.

In terms of educational level, the Mann-Whitney U test was conducted to determine whether there was a statistically significant difference between the perceptions of participants about the magnitude of the problem of violence against teachers. The findings of the analysis are shown in Table 4.

Table 4: Educational level and the perceptions of the participants about the magnitude of the problem

\begin{tabular}{llllll}
\hline Education Level & $\mathrm{N}$ & Mean Rank & Sum of Ranks & $\mathrm{U}$ & $\mathrm{z}$ \\
\hline BA & 486 & 299,44 & 145526,50 & 27185,500 &,- 915 \\
MA / Ph.D & 118 & 315,11 & 37183,50 & \\
\hline Total & 604 & & & \\
\hline
\end{tabular}

When the Mann-Whitney $U$ results shown in Table 4 were examined, it was determined that there is no statistically significant difference between the levels of perceptions of the participants regarding the magnitude of the problem of violence towards teachers in terms of their educational level $(U=27185,500 ; p>0.05)$. Taking into consideration the rank order, it can be said that the participants who have MA or PhD degree perceive the problem of violence towards teachers to be bigger than participants with BA degree but this difference is not enough for a statistically significant difference.

In terms of school type, the Mann-Whitney $U$ test was conducted to determine whether there is a statistically significant difference between the perceptions of the participants about the magnitude of the problem of violence against teachers. The findings of the analysis are shown in Table 5.

Table 5: School type and the perceptions of the participants about the magnitude of the problem

\begin{tabular}{llllll}
\hline School Type & $\mathrm{N}$ & MeanRank & Sum of Ranks & $\mathrm{u}$ & $\mathrm{z}$ \\
\hline General & 231 & 269,21 & 62186,50 & 35390,500 & $-3,857$ \\
Vocational & 373 & 323,12 & 120523,50 & & \\
\hline Total & 604 & & & & \\
\hline
\end{tabular}

When Mann-Whitney U results shown in Table 5 were examined, it was determined that there is a statistically significant difference between the level of perceptions of participants about the magnitude of the problem of violence against teachers in terms of school type $(U=35390,500 ; p<0.01)$. Considering the rank 
order, it can be said that participants in the vocational high schools perceive the problem of violence towards teachers more than teachers who work in general high schools.

In terms of the place where the school was located, the Mann-Whitney U test was conducted to determine whether there was a statistically significant difference between the levels of perceptions of participants about the magnitude of the violence problem for teachers. The findings of the analysis are shown in Table 6.

Table 6: School location and the perceptions of the participants about the magnitude of the problem

\begin{tabular}{llllll}
\hline School location & $\mathrm{N}$ & Mean Rank & Sum of Ranks & $\mathrm{u}$ & $\mathrm{z}$ \\
\hline Urban & 538 & 300,48 & 161656,50 & 16665,500 & -395 \\
Rural & 66 & 318,99 & 21053,50 & \\
\hline Total & 604 & & & \\
\hline
\end{tabular}

When Mann-Whitney U results shown in Table 6 were examined, it was determined that there was no statistically significant difference between the perceptions of participants about the size of the problem of violence against teachers in terms of the location of their schools $(U=16665,500 ; p>0.05)$. Considering the rank order, it can be said that the participants in the rural high schools perceive the problem of violence against teachers as bigger than the participants in the high schools, but this difference is not enough for a statistically significant difference.

In terms of the size of the school, the Kruskal-Wallis test was conducted to determine whether there was a statistically significant difference between the perceptions of participants about the magnitude of the problem of violence against teachers. The results of the analysis are given in Table 7.

Table 7: School size and the perceptions of the participants about the magnitude of the problem

\begin{tabular}{|c|c|c|c|c|c|c|}
\hline School size & $\mathrm{N}$ & MeanRank & $\mathrm{sd}$ & $\overline{\mathrm{x}}$ & $\mathrm{p}$ & Difference \\
\hline $1-500$ & 291 & 277,95 & 2 & 15,700 &, 000 & $1-500 / 501-100 ; 1501+$ \\
\hline $501-1000$ & 192 & 311,18 & & & & \\
\hline $1501+$ & 121 & 347,76 & & & & \\
\hline Total & 604 & & & & & \\
\hline
\end{tabular}

When the results of the Kruskal-Wallis test shown in Table 7 were examined, it was determined that there was a statistically significant difference between the levels of perception of the magnitude of the problem of violence against teachers in terms of school size $\left(\bar{x}_{(2)}=15,700 ; p<0,01\right)$. A different number of MannWhitney U tests were performed to determine which group or groups this difference was for. As a result of the Mann-Whitney $U$ analysis conducted for this purpose, it was found that the difference is between high school students with 1-500 and 501-1000 students $(U=24877 ; z=-2,7146 ; p<0.005)$ and the other difference between high schools with 1-500 and 1501+ students $(U=13521,500, z=-3,889, p<0.001)$. According to the findings, it can be said that the perception level of the participants in the more crowded schools was higher than that of the other respondents working in less crowded schools.

\subsubsection{Findings related to the anxiety level of the participants about violence}

In this section, the data obtained from the second subsection of the questionnaire are investigated. Table 8 shows participants' anxiety level of the participants about violence.

Table 8: Anxiety level of the participants

\begin{tabular}{|c|c|c|c|c|}
\hline Anxiety level of the participants about violence & $\mathrm{N}$ & $\mathrm{M}$ & Std. D. & Interpretation \\
\hline Total & $\begin{array}{l}604 \\
604\end{array}$ & 2,17 & 1,116 & somewhat \\
\hline
\end{tabular}

As can be seen in Table 8, participants seem to have a bit of anxiety level of concerning violence. Following this, the Mann-Whitney $U$ test analysis was run to determine whether there is a statistically significant difference between the levels of anxieties about the personal safety of the participants in their schools in terms of gender. Table 9 shows the results of Mann-Whitney U test. 
Table 9: Gender and Anxiety level of the participants

\begin{tabular}{lllllll}
\hline Gender & $\mathrm{N}$ & MeanRank & Sum of Ranks & $\mathrm{u}$ & $\mathrm{z}$ & $\mathrm{p}$ \\
\hline Male & 326 & 307,33 & 100190,50 & 43738,500 &,- 770 &, 441 \\
Female & 278 & 296,83 & 82519,50 & & & \\
\hline Total & 604 & & & & \\
\hline
\end{tabular}

When the Mann-Whitney U results shown in Table 9 were examined, it was determined that there was no statistically significant difference between the levels of anxiety of the participants about their personal safety in schools in terms of gender $(U=43738,500, p>0.05)$. Considering the rank order, it can be said that the level of anxiety for the personal safety of the male participants is higher than the female participants but this difference is not enough for a statistically significant difference. In terms of professional seniority, the KruskalWallis test was conducted to determine whether there was a statistically significant difference between the level of anxiety of participants about their personal safety in their schools. The results of the analysis are given in Table 10 .

Table 10: Professional seniority and Anxiety level of the participants

\begin{tabular}{llllll}
\hline Professional Seniority & $\mathrm{N}$ & MeanRank & sd & $\overline{\mathrm{x}}$ & $\mathrm{p}$ \\
\hline $1-5$ & 88 & 313,74 & 4 & 7,408 & \\
$6-10$ & 117 & 315,75 & & \\
$11-15$ & 141 & 306,53 & & \\
$16-20$ & 164 & 273,13 & & \\
$21+$ & 94 & 320,70 & & \\
\hline Total & 604 & & & \\
\hline
\end{tabular}

When the results of the Kruskal-Wallis test shown in Table 10 were examined, it was determined that there was no statistically significant difference between the levels of anxiety about personal safety of the participants in terms of occupational seniority $\left(\mathrm{x}^{-}(4)=7,408 ; \mathrm{p}>0,05\right)$.

In terms of educational levels, the Mann-Whitney $U$ test was conducted to determine whether there was a statistically significant difference between the level of anxiety of the participants about their personal safety. The findings of the analysis are shown in Table 11.

Table 11: Education level and Anxiety level of the participants

\begin{tabular}{llllll}
\hline Education level & $\mathrm{N}$ & MeanRank & Sum of Ranks & U & z \\
\hline BA & 486 & 301,18 & 146374,00 & 28033,000 \\
MA / Ph.D & 118 & 307,93 & 36336,00 &,- 394 \\
\hline Total & 604 & & & \\
\hline
\end{tabular}

When the Mann-Whitney U results shown in Table 11 were examined, it was determined that there was no statistically significant difference between the levels of anxiety regarding personal safety of the participants in terms of their level of education $(U=28033,000 ; p>0.05)$. When rank order is taken into consideration, it can be said that the level of anxiety regarding the personal safety of the participants with MA or PhD degree is higher than that of participants with BA, but this difference is not enough for a statistically significant difference.

The Mann-Whitney U test was conducted to determine whether there was a statistically significant difference in levels of anxiety among the participants for their personal safety in their schools in terms of the type of school they serve. Findings related to the analysis result are shown in Table 12.

Table 12: School type and Anxiety level of the participants

\begin{tabular}{llllll}
\hline School Type & $\mathrm{N}$ & MeanRank & Sum of Ranks & $\mathrm{u}$ & $\mathrm{z}$ \\
\hline General & 231 & 271,43 & 62699,50 & 35903,500 & $-3,599$ \\
Vocational & 373 & 321,74 & 120010,50 & \\
\hline Total & 604 & & & \\
\hline
\end{tabular}


When Mann-Whitney U results shown in Table 12 were examined, it was determined that there was a statistically significant difference between the level of anxiety about their personal safety in their schools in terms of the type of school participants work in $(U=35903,500 ; p<0.01)$. Taking into account the rank order, it can be said that the level of anxiety of the participants in the vocational high schools is higher than that of the participants in the general high schools. In terms of location of the school, the Mann-Whitney U test was conducted to determine whether there was a statistically significant difference between the levels of about their personal safety in their schools. The findings of the analysis are shown in Table 13.

Table 13: School Location and Anxiety level of the participants

\begin{tabular}{llllll}
\hline School location & $\mathrm{N}$ & MeanRank & Sum of Ranks & $\mathrm{u}$ & $\mathrm{z}$ \\
\hline Urban & 538 & 302,98 & 163002,00 & 17497,000 \\
Rural & 66 & 298,61 & 19708,00 &,- 201 \\
\hline Total & 604 & & & \\
\hline
\end{tabular}

When the Mann-Whitney U results shown in Table 13 were examined, it was determined that there was no statistically significant difference between the levels of anxiety for personal safety of the participants in terms of the location of their schools $(U=17497,000, p>0.05)$. Taking into account the rank order, it can be said that the participants in the high schools in the city have higher levels of anxiety about their personal safety in their schools than the participants in the rural high schools, but this difference is not enough for a statistically significant difference.

The Kruskal-Wallis test was conducted to determine whether the participants' level of anxiety about their personal safety in their schools varied in a statistically significant manner relative to the size of the schools they are working. The results of the analysis are given in Table 14.

Table 14: School size and Anxiety level of the participants

\begin{tabular}{|c|c|c|c|c|c|c|}
\hline School size & $\mathrm{N}$ & MeanRank & $\mathrm{sd}$ & $\overline{\mathrm{x}}$ & $\mathrm{p}$ & Difference \\
\hline $1-500$ & 291 & 285,06 & 2 & 8,648 & ,013 & $1-3$ \\
\hline $501-1000$ & 192 & 306,80 & & & & \\
\hline $1501+$ & 121 & 337,60 & & & & \\
\hline Total & 604 & & & & & \\
\hline
\end{tabular}

When the results of the Kruskal-Wallis test shown in Table 15 were examined, it was determined that there was a statistically significant difference between the levels of anxiety about personal safety in their schools in terms of school size $\left(\mathrm{x}_{(2)}^{-}=8,648 ; \mathrm{p}<0,05\right)$. A different number of Mann-Whitney $\mathrm{U}$ tests were performed to determine which group or groups this difference was for. As a result of the Mann-Whitney U analysis, it was found that the difference is between the participants working at high schools with 1-500 and 1501+ students $(\mathrm{U}=14509,000 ; \mathrm{z}=-2,9386 ; \mathrm{p}<0.005)$. Depending on the findings, it can be said that the level of anxiety is higher in terms of the personal safety of participants who work in crowded schools.

\subsubsection{Findings related to the cause of violence}

In this section, the data obtained from the third subsection of the questionnaire are investigated to understand the possible reasons for the violence faced by the participants. This section describes the reasons for the occurrence of violence that the participants have been exposed to in their schools. Table 15 shows the views of participants on the cause of the violence they are exposed to.

Table 15. Participants' views regarding the reasons of the violence

\begin{tabular}{|c|c|c|}
\hline Possible reasons & $\mathrm{f}$ & $\%$ \\
\hline The perpetrator comes from a bad family and / or a bad social environment. & 56 & 18,30 \\
\hline The perpetrator is trying to attract attention. & 56 & 18,30 \\
\hline The perpetrator is acting instinctively. & 50 & 16,34 \\
\hline The perpetrator's academic success is low and gets bad grades. & 49 & 16,01 \\
\hline The perpetrator is bored in school and /or does not like school. & 40 & 13,07 \\
\hline The perpetrator is using drugs. & 30 & 9,80 \\
\hline The perpetrator is unhappy with some of my decisions or angry with me. & 11 & 3,59 \\
\hline The perpetrator is behaving like that because he/she is popular or want to be popular. & 7 & 2,29 \\
\hline I have no idea & 7 & 2,29 \\
\hline Total & 306 & 100,00 \\
\hline
\end{tabular}


As seen in Table 15, participants express various opinions as the reasons for the violence they have been exposed to. $18.31 \%$ of the participants $(n=56)$ indicate that the reason for the violence is that the attacker is coming from a bad family or social environment as $18.31 \%(\mathrm{n}=56)$ of the participants think that the possible reason for the violence is because the attacker is seeking attention and trying to attract attention. In addition, $16.34 \%$ of the participants $(n=50)$ think it is because the attacker acts instinctively, without thinking while $16.01 \%$ of them $(n=49)$ report that the perpetrators' academic achievement is low and their getting bad grades could be the reason for the violence. Moreover, $13.07 \%(n=40)$ of the participants think that the attackers are bored with school or hate it and their negative attitude towards the school could be the possible reason for the violence. According to $9.80 \%(n=30)$ of the participants, that perpetrators' using drugs might be the cause of violence towards themselves whereas $3,59 \%(n=11)$ of the participants think the violence could be the result of some decisions they took. While 2, $99 \%(\mathrm{n}=7)$ of the participants express that the perpetrators are popular kids or they act as they do to become (more) popular, 2, 29\% (n=7) state that they have no idea about the cause of violence.

When the table is examined, it is seen that participants point out that the most important cause of the violence they are subjected to is the family the attacker comes from, the society they are in, and that the attacker is trying to attract attention. Moreover, they attributed the cause of the violence to the individual characteristics of the attacker. The fact that the attacker has a low academic achievement, is bored at school, and does not like school are stated other reasons for the violence.

\subsubsection{Findings related to participants' reactions during and / or after the event}

In this section, the data obtained from the third subsection of the questionnaire are examined to understand how the participants act during and/or after the violence. Table 16 shows how the participants react to the violence during and/or after the event.

Table 16: Participants' reactions during and/or after the event

\begin{tabular}{|c|c|c|}
\hline Reactions & f & $\%$ \\
\hline You consulted the school management. & 65 & 19,3 \\
\hline You talked to another teacher about the incident. & 54 & 16,0 \\
\hline You condemned the attacker verbally. & 46 & 13,6 \\
\hline If the perpetrator is a student, you arranged a meeting his/her parents. & 36 & 10,7 \\
\hline You encouraged the aggressor to be positive. & 31 & 9,2 \\
\hline You talked to one of your family members or someone important to you about the event. & 23 & 6,8 \\
\hline You have covered the event. & 16 & 4,7 \\
\hline You reported to the police. & 9 & 2,7 \\
\hline You did not go to the school with the doctor's order the next day. & 9 & 2,7 \\
\hline You attacked back. & 9 & 2,7 \\
\hline You thought about leaving your teaching profession. & 9 & 2,7 \\
\hline You consulted mental health specialists or consultants in the school. & 8 & 2,4 \\
\hline You consulted your union representative. & 7 & 2,1 \\
\hline You asked to be appointed to another school. & 7 & 2,1 \\
\hline You sought professional personal counseling outside the school. & 5 & 1,5 \\
\hline You resigned from your job at school. & 2 & 0,6 \\
\hline You consulted a clergyman. & 1 & 0,3 \\
\hline Total & 337 & 100,0 \\
\hline
\end{tabular}

As shown in Table 16, the participants behaved during or after the violence differently. $19.3 \%(\mathrm{n}=65)$ of the participants reported that they informed and consulted the school management in relation to the violence, while $16.0 \%(\mathrm{n}=54)$ said that they spoke about it with another teacher. $13.6 \%(\mathrm{~N}=46)$ say that they condemned the attacker verbally while $10.7 \%(\mathrm{n}=36)$ attempted to get in touch with the parents of the violent student. While $9.2 \%(n=31)$ of the participants encouraged the attacker to behave positively, $(6.8 \%)(n=23)$ of the participants reported that they talked to someone outside their school who was close to them. The percentage of the participants covering the event is $4.7 \%(\mathrm{n}=16) .2 .7 \%(\mathrm{n}=9)$ of the participants reported the incident to the police, $2.7 \%(n=9)$ of the participants reported that they did not go to school the next day by doctor's order, $2.7 \%(n=9)$ of the participants responded to the aggressor and \% 2, $7(\mathrm{n}=9)$ of the participants expressed that they thought about leaving their profession. $2.4 \%(\mathrm{n}=8)$ of the participants consulted to the psychological counselor at school and $2.1 \%(n=7)$ of the participants contacted their union representatives. While the percentage of the participants who wanted to be appointed to another school was $2.1 \%(n=7), 1.5 \%(n=5)$ of the participants said that they talked to a psychologist or psychiatrist outside the school. $0.6 \%(\mathrm{n}=2)$ of the participants stated that they had left their post at the school, while $0.3 \%(n=1)$ of the participants said that they saw a clergyman. 
When the table is examined, it is seen that in case of any violence, the participants first report the problem to the school administration and they talk to a teacher about the event mostly. They also seem to react verbally to the aggressor, encourage them to behave positively and attempt to meet with the family of the attacker. Some participants indicated that they sought support from their immediate surroundings, while others said they closed the matter. It is seen that there are fewer participants who resort to official ways, who respond to the aggressor, seeking psychological support from an expert inside or outside of the school.

\subsubsection{Findings related to Precautions taken by the participants}

In this section, the data obtained from the third subsection of the survey are examined to understand what precautions are taken by the participants to protect themselves from violence. Table 17 shows the participants' views on the precautions they take in order to avoid violence.

Table 17: Precautions participants take

\begin{tabular}{lll}
\hline Precautions & $\mathrm{f}$ & $\%$ \\
\hline - You wait in the teachers' room until certain students left the school. & 32 \\
- You leave your money and valuables at home for not being stolen. & 44,4 \\
- After school hours, you avoid being alone in school, coming to social activities in school or after class hours. & 16 & 22,2 \\
- You stay with a group of teachers to improve your personal safety. & 11 & 15,3 \\
- You stay at home unless you have to go out. & 7,7 & 3 \\
- You bring pepper gasses, whistles, etc.. to protect yourself & 4,2 & 2 \\
- You refrain from interfering with students in order to avoid harm. & 2,8 \\
\hline Total & 1,4 \\
\hline
\end{tabular}

As shown in Table 17, the participants indicate that they have taken various measures to protect themselves from violent incidents. While 44.4\% $(n=32)$ of the participants expressed that they wait in the teachers' lounge until certain students leave, 22.2\% $(n=16)$ of the participants stated that they do not bring their money and valuables to school. $15.3 \%(n=11)$ of the participants do not come to school if they do not have to or stay alone after class hours as $9,7 \%(n=7)$ of the participants stated that they stayed with a group of teachers. Whereas $4.2 \%(n=3)$ preferred to stay at home unless they had to, 2.8\% $(n=2)$ of the participants stated that they had something with them to protect themselves. In addition, $1.4 \%(n=1)$ of the participants said that they refrain from interfering with the students' quarrels.

When the table is examined, it is seen that most of the participants stated that they prefer not leaving the school till some certain students leave the school, they also leave their valuables and money at home, and stay away from the school outside their working hours. Whatever the case, the teachers tend to interfere with the fighting and discussions between the students.

\subsection{Qualitative data}

\subsubsection{Teachers' Views Related to the Factors That Increase Violence towards Teachers}

In this section, the data obtained from the sixth part of the questionnaire are examined to understand what the participants think about the factors that may increase the violence towards teachers. In this part, the participants were asked about the most important 3 factors that they think are the effect of increased violence towards teachers in open-ended questions. Accepted responses are grouped into organizational, family, community, individual, media \& internet and other factors. Table 18 shows the views of the participants for what they think is the effect of increasing violence against teachers in schools.

Table 18: Factors that participants think might be the effect of increasing violence

\begin{tabular}{lll}
\hline Factors that increase violence & $\mathrm{f}$ & $\%$ \\
\hline - Institutionalfactors & 107 & 23,2 \\
- Family-relatedfactors & 101 & 21,9 \\
- Socialfactors & 87 & 18,9 \\
- Individualfactors & 73 & 15,8 \\
- Media \& Internet-relatedfactors & 50 & 10,8 \\
- Teacher-relatedfactors & 43 & 9,3 \\
\hline Total & 461 \\
\hline
\end{tabular}


As seen in Table 18, the participants point out that the various elements have an effect on the increase of the incidents of violence against teachers. While $23.2 \%(n=107)$ of the participants stated that institutional factors are effective in the increase of violence, $21.9 \%(\mathrm{n}=101)$ of the participants emphasized family factors. While $18.9 \%(n=87)$ of the participants put emphasis on social factors, $15.8 \%(n=73)$ of the participants expressed individual elements play more roles in terms of violence. While the percentage of the participants was $10,8 \%(n=50)$ who indicated that media and internet has an effect on the increase of violence, $9,3 \%(n=43)$ of the participants stated that the other factors could be the reason for the increase of violence.

As for the institutional factors in increasing violence towards teachers, some of the most remarkable points include managerial inadequacy, lack of discipline, disregard of complaints, security shortcomings, free dress code, crowded classes, low academic achievement, inadequate family-school relationship and so on. To clarify better, the participants' responses studied in details and some quotations are given.

Some participants have stated that school discipline is not adequately ensured in schools because some people who are in managerial positions do not deserve to be in certain positions. Also, the punishments given to the students are insufficient and the teachers' complaints related to their victimization are not seriously taken into consideration by the school management or the inspectors. Even if they file complaints, nothing good comes out of their complaints so they see there is no point in filing a complaint. According to some participants, teachers who made a complaint face pressure or they are being silenced by the school management, supervisors and inspectors. Moreover, the teachers are blamed for the violence so they tend to keep it to themselves. Thus, most participants believe that they are ignored, left alone in an intolerant, loveless, non-communicative environment and they feel they are seen as baby sitters or slaves and that the teacher's profession has suffered serious loss of respectability. Some participants think that their schools are not safe enough and more security precautions at school entrance and exit as well as the number of security officers required. In addition, some participants say that discipline and control problems arise because of free dress code at schools and it makes is difficult to supervise the people who enter the school because some strangers may come in school as easily as the students. Besides, some participants say that they have difficulty in establishing a relationship with students because of overcrowded classes, academic curriculum is very intensive, academic achievement of students is very low and failure and lack of communication are effects of increasing violence incidents. In general, participants have stated that the burden placed on them and the expectation from them are very high and that the bill for all kinds of problems is cut off to them and that they are usually accused and blamed in every case and that they are exposed to various violent incidents. The fact that the school-family cooperation is not strong enough, the school guidance service cannot be provided in a healthy way, and that a biased administrative staff is in school administration are some of the factors that might have an effect in teacher victimization.

As for the family-related factors in increasing violence towards teachers, some of the most remarkable points include domestic violence, low socioeconomic level, separated families, disciplinary practices and so on. To clarify better, the participants' responses studied in details and some quotations are given.

Some participants have stated that students who tend to become violent are often experiencing domestic violence at home and that they see violence as a solution. They are also affected by negative examples in their surroundings. Because they do not see enough interest, love, or come from separated families. According to some participants, the attacks are carried out by students who are were brought up in a highly undisciplined environment, sometimes spoiled and not being held responsible for any actions they make because they are male. In addition to those above, parents' socioeconomic or sociocultural level play an important role on how they behave. Some participants argue that students who are educated by low-income parents in an unloved, highly disciplined or undisciplined environment, without being heard are more prone to violence.

As for the social factors that are claimed to have an impact on increasing violence against teachers, some of the most remarkable points include deterioration of social values, violence in society, poverty and so on. To clarify better, the participants' responses studied in details and some quotations are given.

Some participants pointed out that weaknesses in the belief system is the culprit because of the deterioration of social values, students do not show respect to their elders or act decent enough. In addition, the existence of the negative examples and increased violence in the society, poverty and insecurity are believed to have an effect on the increase of the violence. Moreover, the increasing population, polarization of politics, general situation of the country, loss of respect for the teacher in the society and changes in the education system are believed to be the reasons for the increase of violence towards teachers. 
As for the individual factors that are claimed to have an impact on increasing violence against teachers, some of the most remarkable points include substance use, hopelessness, purposelessness, lack of empathy and so on. To clarify better, the participants' responses studied in details and some quotations are given.

Some participants state that offensive students use substance, that they are hopeless, purposeless, and have no future expectations. In addition, some teachers say that the attackers are those who are not able to establish dialogue with others, are preoccupied, prejudiced, uninterested, and lack affection to others, influenced by their peers. In addition, teachers point out that some attackers come from rural areas, live in a low socioeconomic environment, and do not have good examples without good role models in their surroundings. Some even take fictional characters as role models and try to act like them. Some teachers say that some aggressors usually have poor academic achievement, do not love school or believe the necessary of education or the education will help them be successful in life or some turn to violence because they blame others for their own failure. Some even resort to violence to be visible, recognized or thinking that they would profit from what they do as to become popular or so.

As for the media-internet related factors that are claimed to have an impact on increasing violence against teachers, some of the most remarkable points include violence on media, uncontrolled use of internet, social networking websites and so on. Some participants point out that violent movies, TV series and visuals encourage violence and that it is an influence on students' future goals. It is stated that in the specific series and films made about the school, the teachers are misrepresented, the negative student behaviors are exalted, and the wrong messages are given. According to some teachers, one of the main reasons for the conflicts between teachers and students in the class are due to the fact that students turn to their smartphones, play games or surf the Internet instead of listening to lessons during the courses. Moreover, it is believed that some games the students play make them aggressive, also they make them become individuals who cannot communicate and express themselves in a peaceful way, and as a result they tend to solve their problems with their fists.

In addition to factors aforementioned, there are some teacher-related factors that are claimed to have an impact on increasing violence against teachers. Some participants argue that some teachers' wrong attitudes towards students (not understanding the student, not listening, provoking the student, giving the student a high score, pampering the student, paying too much attention to the student, not being sufficiently informed about the student, not understanding the physical and psychological changes experienced by the student) might cause an increase in the violence towards them.

\section{DISCUSSION AND CONCLUSION}

According to teacher opinions, violence against teachers in high schools in Niğde is not a serious problem and teachers are not very concerned about their safety. This finding seems consistent with the findings of Meadows's study [5]. As Meadow stated, teachers do not seem to be worried or anxious about teacher victimization, but the numbers say otherwise. However, according to findings, participants' views on the magnitude of the problem of violence differ according to their professional seniority. It seems that the teachers who started the profession recently perceive the problem bigger. This finding seems to be consistent to the findings of some studies in the literature [8][16][17][18]. In addition, participants working in vocational high schools and those working in crowded high schools think that the problem is bigger than those working in general or less crowded high schools. In terms of personal safety it was found that participants working in the vocational high schools and participants working in large schools had higher levels of anxiety. These findings may provide a starting point for recognizing the extent of the problem and shed light on the areas that need special attention.

This finding seems to be consistent with the findings of some studies. In some studies, it is also found that vocational high schools are riskier for school violence [4][19]. As for the size of the school, it is generally agreed that more crowded schools and classrooms are riskier than the less crowded ones for several reasons $[12][20][21][13][22][23]$.

Based on the findings obtained as an analysis of the qualitative data of the study, organizational factors seem to be the leading causes of violence towards teachers. In the literature, organizational factors also are mentioned as one of the leading factors for violence [3][2][22][24][25]. For the prevention of violence against teachers, serious measures need to be taken by school administrators. Disciplinary rules must be strictly and impartially applied. Students need to be provided with proper guidance, social, sportive, extra-curricular activities and opportunities that meet their interests and needs. Effective communication and cooperation 
between school management and students, school management and teachers might also be helpful. In addition to this, it can be useful to cooperate with the parents, to increase the security measures in the school and to cooperate with the police. In addition, a democratic leadership, assigning the correct people for the administrative posts, taking the complaints seriously may be some of the factors that can be effective to prevent violence. It is important for the school to provide a variety of programs and opportunities for its own interests and needs, where the rules of violence are enforced fairly, openly and consistently, where the student feels that the student is important, valuable and respected [26][22][23]. It is also necessary to recognize the student, to create a sense of community, to adopt effective, student-centered education models, to create school-class rules clearly and meaningfully, to implement effectively, to strengthen family-school cooperation, and to effectively organize school and classroom physical environment [27]. It is also important to give effective guidance services in school, to provide sufficient and various social and sportive activities for students, to give up repressive discipline methods and practices, and to end erroneous educational practices [28].

As for the family-related factors in the prevention of violence against teachers, family education is put emphasis on. Educating parents, establishing school-family cooperation, encouraging the parents to take responsibility for their children could be effective in solving the problem. As stated in the literature, for the child to acquire moral values and socialize, a healthy family-child relationship and a positive role model is important [29][30]. On the other hand, lack of these and factors such as family members' level of commitment to each other, inadequate supervision within the family, inconsistent, punishment based disciplinary practices, loveless, irrelevant, neglected family environment, domestic violence, abuse and socioeconomic level of the family may cause violence[1][21]. In Turkey, disciplinary practices of the parents, maltreatment of children such as violence, exclusion, intimidation and suppression, and the parents not giving enough time to their children and neglecting them are mentioned some of the reasons for violence [31]. Children who grow up neglected, unloved in a in a hateful, environment with bad examples can develop a positive attitude towards violence and accept behaviors such as violence as correct [32]. For this reason great burdens fall on families for the resolution of violence.

In addition to family-related factors, some individual factors in the prevention of violence against teachers are as follows. It is stated that violent students have no future goals or are hopeless for the future, so first they need guidance to increase their motivation for their education and help in their goal setting. Also factors such as low academic achievement, school indifference, school stress, school love, low self-esteem, disliking the school, disciplinary problems may lead to children's violence [33][23]. Children who do not have healthy, and strong sense of morality, have bad friends, are exposed to violence in the family or in school and have low academic achievement can try to attract attention by turning to violence [12][34][23]. Therefore, communicating with students, loving them, helping them with their economic, psychological and other problems might be fruitful. It is important to identify the students who have problems and to provide them with the necessary help and support, to show that they are valuable, respected and appreciated could be suggested that in the prevention of violence.

It is claimed that certain characteristics of the society such as politics, poverty, crime rate in the society, corruption of values, may also lead to school violence in this study as in other studies in the literature [1][35]. It is also claimed that there is a tendency for violence to be used as a means of solving problems in Turkish society, that violence is promoted in certain situations, and that as a result, children who socialize in such an atmosphere and in such an atmosphere with such values may be able to resolve conflicts with violence by violence [31]. Therefore, religious and moral education may be also effective in the prevention of violence but to prevent violence in school, the government should work to prevent violence in society, fight against the inequalities and poverty.

It is also believed that teachers play an important role in preventing violence towards themselves as it is found in this study [36]. Teachers' inconsistent, negative behaviors to the students, their lack of trust to the students, their exercising physical, psychological punishment can lead to violence in children [37][38]. It is important to know the student well, to be a loving and caring person who is competent in classroom management and emotional management with great deal of knowledge about the physiological and psychological development of the young. Using teaching methods and techniques appropriate to the students rather than the classical methods might be useful as well as being equal and consistent in their attitudes towards the students in the prevention of teacher victimization [39][36]. In general, the importance of teacher education, school-family cooperation, school community cooperation and counseling services is emphasized in preventing school violence [40]. It is believed that students who are respected by their parents, teachers, and peers will be 
more successful academically and socially, and as a result will resort to undesirable behavior such as violence [41].

In this study, it is also found that the media, films and serials, can be an effect on school violence. Today, violence images are frequently encountered in various media, films and serials. With these images, violence is perceived as a part of everyday life, and even in some movies and TV series, violence is superseded, normalized and transferred as a solution [21]. It is thought that this may lead to the children' identification of themselves with these fictional heroes, and taking them as role models can trigger the tendency of violence in children [42][43]. In short, television programs, computer and video games with violence can negatively affect children and lead them to violence [24][23][44]. Therefore, media literacy and controlled Internet use may also be helpful for the problem.

\section{RECOMMENDATIONS FOR INTERVENTION}

Effective implementation of discipline at school, effective counselling service, increased social activities for students according to their interests, increase of extra-curricular activities, acceptance of the existence and seriousness of the problem by principals and others, improvement of school family cooperation and increasing security measures might be useful. The teachers should not be left alone and defenseless against the parents and students.

The loss of prestige of the teaching profession in the society is one of the reason. It can be said that increasing the social awareness will contribute to the prevention of the problem so working on the recovery of the status of the teaching profession that may have an effect.

Factors such as the physical and psychological changes especially in adolescence, the socioeconomic and sociocultural level of the students and their families, the lack of interest of the family in their children and the lack of any academic expectations of the children in the future can lead to violence or cause violence to be seen as normal and in some cases necessary. In this respect, the teachers' competency about puberty psychology, the family education, economic and cultural investments could prove to be fruitful.

Violence could be the result of an impact-response, therefore, teachers' attitudes and behaviors are also important. Teachers' professional inadequacy, the inconsistency in attitude and behavior of them may be the basis for violence. In this case, it can be said that teachers' proficiency in the fields such as classroom management, emotional management, field knowledge can be increased, and it can be a positive effect of the in vocational trainings and the elimination of these deficiencies.

In addition, the most basic reason for the problems experienced in the classroom between the teacher and the student is that the student deal with the smartphone in the classroom, use the internet or play games. Given the place of smartphones, the Internet and the media in the lives of young people, it can be said that it is useful to make students aware of the correct use of these tools. Also media literacy and providing positive examples on the media, films and serials instead of bad examples may have a positive effect in the prevention of violence.

The place of teachers in the life of children is very important. Their well-being is very important for students, school, education system and society. But there is a violent increase towards teachers, which seems to indirectly threaten healthy teacher-student relations and student learning. Teachers are important for the future of a society. Therefore, it is necessary to carry out the necessary studies to prevent violence against them.

\section{REFERENCES}

[1] B. Dönmez, "Okul güvenliği sorunu ve okul yöneticisinin rolü," Kuram ve uygulamada eğitim yönetimi, no. 25, pp. 63-74, 2001.

[2] D. Karal, "Korkmadan öğrenmek; Okul ve okul çevresi güvenliği," Uluslararası Stratejik Araştırmalar Kurumu Sosyal Araştırmalar Merkezi Uşak Rapor No:11-06, Ankara, 2011.

[3] İ. Çınar, "Okullarda şiddet: Dağın ili yamacını da görebilmek," in Okullarda şiddet ve çocuk suçluluğu, A. Solak, Ed., Ankara, Hegem, 2007, pp. 1-18.

[4] M. Khoury-Kassabri, R. A. Astor and R. Benbenishty, "Middle eastern adolescents' perpetration of school violence against peers and teachers: A cross-cultural and ecological analysis," Journal of Interpersonal Violence, vol. 24, no. 1, pp. 159-182, 2009.

[5] R. J. Meadows, Understanding violence and victimiztion, New Jersey: Pearson, 2014. 
[6] C. d. Wet, "Victims of educator-targeted bullying: a qualitative study," South African Journal of Education, no. 30, pp. 189-201, 2010.

[7] C. M. Wilson, K. S. Douglas and D. R. Lyon, "Violence against teachers: Prevalence and concequences," Journal of Interpersonal Violence, vol. 26, no. 12, pp. 2353-2371, 2011.

[8] A. Martinez, S. D. McMahon, D. Espelage, E. M. Anderman, L. A. Reddy and B. Sanchez, "Teachers' experiences with multiple victimization: Identifying demografic, cognitive and contextual correlates," Journal of School Violence, vol. 15, no. 4, pp. 387-405, 2016.

[9] S. McMahon, A. Martinez, D. Espelage, C. Rose, L. A. Reddy, K. Lane, E. M. Anderman, C. R. Reynolds, A. Jones and V. Brown, "Violence directed against teachers: Results from a national survey," Psychology in the Schools, vol. 51, no. 7, pp. 753-766, 2014.

[10] S. M. Özdemir, "An investigation of violence against teachers in Turkey," Journal of Instructional Psychology, vol. 39, no. 1, pp. 51-62, 2012.

[11] J. N. Kondrasuk, "Violence affecting school employees," Education Faculty Publications and Presentations, pp. 638-647, 2005.

[12] B. Dönmez and N. Özer, Yöneticiler, öğretmenler, öğrenciler ve veliler için okul güvenliği ve güvenli okul, Ankara: Nobel, 2009.

[13] A. Gregory, D. Cornell and x. Fan, "Teacher safety and autoriative school climate in high schools," American Journal of Education, no. 118, pp. 401-425, 2012.

[14] , J. W. Creswell, Qualitative inquiry \& research desing: Choosing among five approaches., Los Angeles: SAGE Publications, 2013.

[15] , A. M. Huberman and M. B. Miles, Data management and analysis methods, 1994.

[16] M. Lokmic, s. Opic and V. Billic, "Violence against teachers - rule or exception?," International Journal of Cognitive Research in Science, Engineering and Education, vol. 1, no. 2, pp. 1-6, 2013.

[17] A. Ertürk, "Öğretmen ve okul yöneticilerinin okul ortamında maruz kaldıkları bullying davranışları (Mobbing in primary school)," Unpublished doctoral thesis. Gazi University, Institute of Educational Sciences, Ankara, 2011.

[18] N. Cumaoğlu, "The exposure of primary school teachers to bullying: An analysis of various variables," Social Behavior and Personality An International Journal, vol. 35, no. 6, pp. 789-802, 2007.

[19] T. Ayas and M. B. Horzum, "Exploring the teachers' cyber bullying pereption in terms of various varibales," International Online Journal of Educational Sciences, vol. 3, no. 2, pp. 619-640, 2011.

[20] , J. Garbarino, "Making sense of school violence: Why do kids kill?," in School violence: Assessment, managemet,prevention, M. Shafii and S. L. Shafii, Eds., Washington, DC, American Psychiatric Publishing,Inc, 2001, pp. 3-24.

[21] B. Koç, Okullarda şiddet, II. ed., İstanbul: Yazı, 2011.

[22] [L. T. Flaherty, School Violence, M. Shafii and S. L. Shafii, Eds., Washington, DC: American Psychiatric Publishing, 2001.

[23] , L. J. Veltkamp and A. Lawson, "Impact of trauma in school violence on the victim and the perpetrator: A mental health perspective," in School violence and primary prevention, T. W. Miller, Ed., New York, Springer, 2008, pp. 185-200.

[24] H. Odacı, "Çocuk suçları ve şiddet olayları," in Okullarda Şiddet ve Çocuk Suçluluğu, Ankara, Hegel Yayınları, 2007, pp. 55-76.

[25] B. Preble and R. Gordon, Transforming school climate and learning: Beyond bullying and compliance, Thousand Oaks: Corwin, 2011.

[26] S. Braaten, "Creating safe schools," in School violence intervention: A practical handbook, 2. ed., J. C. Conoley and A. P. Goldstein, Eds., New York, The Guilford Press, 2004, pp. 54-67.

[27] S. H. Striepling-Goldstein, "The low-aggression classroom: A teacher's view," in School violence intervention: A practical handbook, 2. ed., J. C. Conoley and A. P. Goldstein, Eds., New York, The Guilford Press, 2004, pp. 23-53.

[28] A. Üstün, M. Yılmaz and Ş. Kırbaş, "Gençleri şiddete yönelten nedenler," in Okullarda Şiddet ve Çocuk Suçluluğu, Ankara, Hegem Yayınları, 2007, pp. 109-131. 
[29] S. L. Christenson, A. R. Anderson and J. A. Hirsch, "Families with agressive children and adolescents," in School violence intervention: A practical handbook, 2. ed., J. C. Conoley and A. P. Goldstein, Eds., New York, The Guilford Press, 2004, pp. 359-399.

[30] E. Ersanlı, "Çocugun davranışlarının biçimlenmesinde rol model davranışlarının etkiksi," in Okullarda şiddet ve çocuk suçluluğu, A. Solak, Ed., Ankara, Hegem, 2007, pp. 321-327.

[31] Z. Kızmaz, "Okullardaki şiddet davranışının kaynakları üzerine kuramsal bir yaklaşım," C.Ü. Sosyal Bilimler Dergisi, vol. 30, no. 1, pp. 47-70, 2006.

[32] K. Allen, "Cognitive perspective to violence expression," in Violence in schools: Issues, consequences, and expressions, K. Sexton-Radek, Ed., Wesport, Praeger, 2005, pp. 49-72.

[33] V. Bademci, "Tehlike (risk) altındaki çocuklar," in Okullarda şiddet ve çocuk suçluluğu, Ankara, HEGEM, 2007, pp. 171-186.

[34] K. Kyle and S. Thompson, "The roles of moralilty development and personal power in mass school shootings," in School violence and primary prevention, T. W. Miller, Ed., New York, Springer, 2008, pp. 95-123.

[35] İ. Gökdaş, "İlköğretimde şiddet," in Okullarda Şiddet ve Çocuk Suçluluğu, Ankara, Hegem, 2007, pp. 263-295.

[36] J. S. Yoon and E. Barton, "The role of teacher in school violence and bullying prevention," in School violence and primary prevention, New York, Springer, 2008, pp. 249-275.

[37] V. Özpolat and N. Bayındır, "Vaka sorgulama tekniği ile okulda fiziksel ceza ve çocuk saldırganlığı," in Okullarda şiddet ve çocuk suçluluğu , Ankara, Hegem Yayınları, 2007, pp. 37-54.

[38] J. M. Ruff, G. Gerding and O. Hong, "Workplace violence against K-12 teachers: implentation of preventive programs," AAOHN J., vol. 52, no. 5, pp. 201-209, 2004.

[39] H. R. Keller and R. C. Tapasak, "Classroom-based approaches," in School violence intervention: A practical handbook, 2. ed., J. C. Conoley and A. P. Goldstein, Eds., New York, The Guilford Press, 2004, pp. 103-120.

[40] D. L. Espelage and S. M. Swearer, "Current perspectives on linking school bullying research to effective prevention strategies," in School violence and primary prevention, T. W. Miller, Ed., New York, Springer, 2008, pp. 335-353.

[41] M. Thompson, B. Burcham and K. McLaughlin, "The roles of teachers in school volence and bullying prevention," in School violence and primary prevention, New York, Springer, 2008, pp. 229-248.

[42] D. Gözütok, Eğitim ve şiddet, Ankara: Gazi Kitabevi, 2008.

[43] D. W. Johnson and R. T. Johnson, Reducing school violence through conflict resolution, Alexandria, Virginia: ASCD Books, 1995.

[44] C. İpek, "Okullarda şiddet bağlamında ilköğretim programına konan medya okur-yazarlığı dersi," in Okullarda şiddet ve çocuk suçluluğu, A. Solak, Ed., Ankara, Hegem, 2007, pp. 235-262. 